\title{
УOBOBНАВCTBO. NITEPATУPOBHABCTBO
}

\author{
УДК 801.5+802.0 \\ DOI https://doi.org/10.24919/2308-4863/37-2-13
}

\begin{abstract}
Вікторія ЗАХАРЧУК, orcid.org/0000-0002-3677-5217 викладач кафедри теоретичної та прикладної лінгвістики Державного університету «Житомирська політехніка» (Житомир, Україна) vikazakharchuk94@gmail.com
\end{abstract}

Ірина МЕЛЬНИЧЕНКО, orcid.org/0000-0001-6732-5342 старший викладач кафедри теоретичної та прикладної лінгвістики Держсавного університету «Житомирська політехніка» (Житомир, Україна) arabica240@gmail.com

\section{СФЕРИ ЗАСТОСУВАННЯ ТА ОСНОВНІ ФУНКЦІЇ ЕВФЕМІЗМІВ У СУЧАСНІЙ АНГЛІЙСЬКІЙ МОВІ}

\begin{abstract}
Світ стрімко розвивається, разом з ним розвивається людство, виникають нові речі, поняття, з'являються відкриття та повалюються режими. Мова є свідком всіх подій, вона запам'ятовує всі події $i$ закарбовує їх словами у людській пам'яті. Кожна культура має свої поняття, ідеї, які підпадають під заборону через їх розвиток, а деякі, навпаки, вважають прийнятними. На основі иього виникає поняття політичної коректності, яке спрямоване на регулювання відносин між різними культурами, соціальними, віковими, гендерними групами. Це поняття встановлює рамки, вихід за які може спричинити неприємні наслідки. Це явище тісно пов'язане з навмисним пом'якшенням та уникненням табуйованої лексики, щзо, своєю чергою, є вимогою сучасного суспільства.

Неможливо уявити мову окремо від суспільства, в якому вона функціонує, як $і$ не можна заперечувати наявність активного двостороннього зв'язку мови та сочіуму. Одним із проявів такої щільної взаємодії є віддзеркалення суспільних заборонних одиниць у мові. Табу у культурі, релігії, повсякденному житті віддзеркалюються у словниковому складі, граматичній структурі мови, стилістичних засобах, якими користуються члени мовної спільноти. Словесні табу та евфемізми виникають у мовленні в результаті заборони на використання слів сакрального або ж негативного змісту і формують комунікативну поведінку будь-якої культури.

Отже, поки існуватимуть непристойні теми, про які люди не бажають говорити прямо? або ті, які не можуть бути озвучені з погляду на їх грубість чи недоречність у сучасному суспільстві, будуть використовуватися і існувати евфемізми. Фактично спілкування людей неможливе без використання евфемізмів, щзо покликані усунути почуття незручності у комунікативній взаємодії. Але існує певна можливість зникнення у майбутньому евфемізмів і вираження думок у їх первісному стані не буде більше вважатися недоречним чи непристойним.

Ключові слова: лінгвістичні табу, евфемізми, мовна картина світу, концептуальна картина світу, міжкультурна комунікація.
\end{abstract}

Viktoriia ZAKHARCHUK, orcid.org/0000-0002-3677-5217 Lecturer at the Theoretical and Applied Linguistics Department Zhytomyr Polytechnic State University (Zhytomyr,Ukraine)vikazakharchuk94@gmail.com

Iryna MELNYCHENKO, orcid.org/0000-0001-6732-5342 Senior Teacher at the Theoretical and Applied Linguistics Department Zhytomyr Polytechnic State University (Zhytomyr, Ukraine) arabica240@gmail.com

\section{FIELDS OF APPLICATION AND MAIN FUNCTIONS OF EUPHEMISMS IN MODERN ENGLISH}

The world is rapidly evolving, as a result humanity is evolving too, new ideas, concepts are emerging, discoveries are made and political regimes change. Language is a witness to all events; it remembers everything and engraves it in words, 
which remain in human memory. Each culture has its own concepts, ideas, which became prohibited due to their cultural development, and some, on the contrary, now considered as acceptable. Based on this, the concept of political correctness appeared, which aims to regulate relations between different cultures, social, age, gender groups. This concept sets the framework, breaking it can cause unpleasant consequences. This phenomenon is closely linked to the deliberate mitigation and avoidance of taboo vocabulary, which in turn is a requirement of modern society.

It is impossible to imagine a language apart the society in which it operates, just as there is no denying the existence of an active two-way connection between language and society. One manifestation of this dense social interaction is a reflection of forbidden words in languages. Taboos in culture, religion, everyday life are reflected in the vocabulary, grammatical structures of language, stylistic means used by members of the language community. Verbal taboos and euphemisms arise in speech as a result of prohibition on use of sacred words or words with negative meaning and form the communicative behaviour of any culture.

So, as long as there are obscene topics that people do not want to talk about directly or that cannot be voiced in terms of their rudeness or inappropriateness in today's society, euphemisms will exist. In fact, people simply cannot speak today without the use of euphemisms, they will not feel comfortable. But in the future, euphemisms may disappear and the expression of thoughts in their original state will no longer be considered inappropriate or obscene.

Key words: linguistic taboos, euphemisms, linguistic world-image, conceptual world-image, intercultural communication.

Постановка проблеми. У сучасному світі все більше прогресує явище міжкультурної комунікації. Через розбіжності у нормах моралі, традиції та культуру спілкування у сучасному суспільстві змінюються вимоги до етичної та культурної комунікації. Лінгвістичні табу або ж евфемізми $\epsilon$ невід'ємною частиною міжкультурної комунікації. Для успішної комунікації необхідно розуміти походження забороненої лексики, сфери, де вона найбільше уживана, і які є шляхи уникнення такої специфічної лексики.

Аналіз досліджень. Евфемізми як мовне явище протягом останніх років стали центром особливої уваги і досліджень. Вони поширюються у різних мовленнєвих сферах, а як результат проникають у повсякденне життя людей. Дослідження лінгвістично табуйованої лексики дозволяє глибше зрозуміти співвідношення мовної та концептуальної картини світу.

Дослідженням цієї проблеми займалися такі відомі лінгвісти, як Ж. Вандрієс, Е. Бенвеніст, І. Р. Гальперін, Л. Блумфілд, С. Г. Тер-Мінасова та багато інших.

Евфемізми покликані пом'якшувати звучання гострих та морально неприйнятних одиниць мови. Вони призводять до більш нейтрального сприйняття жорстокості, непристойності у мові.

У ході дослідження було виявлено певні функції, які вони представляють. Евфемізми дають можливість приховувати ті аспекти, про які людина не бажає говорити відверто. Страх людини перед невідомим, надприродним, почуття огиди чи неприязні - це основні причини появи спеціальної лексики.

Мета статті полягає у тому, щоб розглянути та проаналізувати наявні класифікації евфемізмів, окреслити їх функції та визначити способи уникнення лінгвістичних табу.
Виклад основного матеріалу. Кожна країна формує своє розуміння того, що слід відносити до табу, а яка лексика $\epsilon$ цілком прийнятною у спілкуванні. Так, наприклад, в Англії недоцільним вважається запитання про зарплатню та вік людини. У разі неможливості уникнення такого запитання перевага надається евфемістичнім висловленням. У Китаї, навпаки, відкрито говорять про вік та гроші, однак сфери екскреції та сексуальної тематики суворо заборонені. Тому ознайомлення і знання основних тем, що є табуйованими у тому чи іншому суспільстві і способи їх уникнення за допомогою застосування евфемізмів, $\epsilon$ необхідними у сучасній комунікації (Денисенко). Саме тому існують чітко визначені сфери застосування евфемізмів:

1) Людська екскреція

У сучасній англійській мові застосування слів 3 такою конотацією суворо заборонене, вони вважаються табу. Раніше для висловлення таких потреб використовувалися відповідники move the bowels, pass water. Нині вони вважаються грубими та неетичними. В медичній сфері широко застосовуються defecate, urinate, а оскільки вони належать саме до медичної термінології, то вважаються в міру прийнятними. У суспільстві люди зазвичай використовують інші відповідники, які $є$ свого роду «обхідним шляхом» у мові. Сюди належать найпопулярніші "answer the call of nature", "do one's needs". "Rest room", "powder room", "loo", "john” теж використовуються для того, щоб замінити слово туалет. "Where do you wash your hands", "where do you pee and роо" є відповідниками у розмові з дітьми, адже вони можуть не зрозуміти «обхідні» еквіваленти (Великорода, 2008).

2) Смерть та хвороби

Використання лексичних одиниць, пов'язаних зі смертю й хворобою, викликає почуття страху. 
Багато хто вірить, що називати слова, які мають відношення до цих явищ, небезпечно, тому використовують "if something happens to те" замість "when I die". Замість “die" використовують фрази пом'якшувального характеру "pass away", "go to his reward", "answer the call of God", "go home", "to have a better place", "depart" , "go west" (Chunming, 2013).

Назви серйозних хвороб, які є проблемою суспільства, нині також намагаються замінити на евфемістичні відповідники. Щоб уникати назви Cancer, використовують "Big C" або "terminally ill”. Так само з психічними захворюваннями, щоб звучати лагідніше, говорять "he is not all there", "she is a little eccentric/a little confused".

3) Слова на позначення частин тіла жінки та чоловіка

На думку дослідника Денга, слова, які стосуються анатомії та сексу, цікаво досліджувати саме в контексті англійської мови на прикладі Америки. Жінки XIX століття ніколи б не сказали breast чи leg навіть у відношенні до курки, так само 3 white meat та dark meat. Невихованим у той час вважалося вживання "going to bed", відповідником був “to retire".

Сексуальна революція 1960x років у Сполучених Штатах призвела до того, що молоді люди стали почуватися вільніше, ніж 15-20 років тому, і така тема стала прийнятним явищем в американській культурі (Crawford, 2008).

4) Так звані four-letter words

Люди нині є більш толерантними у використанні таких слів, як “fuck", “tits”, “damn”, і їх визначають як "four-letter words". Наприклад, на вулицях Лондона можливо побачити вивіску магазину з назвою, яка привертає увагу "FCUK", хоча насправді розшифровується як "French Connection United Kingdom”. Звичайно, незважаючи на сексуальну революцію, ці слова все ще $\epsilon$ забороненими в усному та писемному мовленні. В 1963 році Ерік Партридж включив слово "fuck" y "Dictionary of Slang and Unconventional English". Заміна літери "u" на зірочку в слові, наведеному вище, не зупинило хвилю невдоволень, усі примірники були вилучені, і навіть сьогодні неможливо знайти цей словник у книгарнях. Після виходу “Lady Chatterley's Lover" написаної Д. Г. Лоуренсом, таке слово з'явилося в пресі і поширилося серед літературних праць. Хоча нині в публічних виступах усе ще заборонене використання зазначених слів і вони не завжди внесені до словників (Chunming, 2013).

\section{5) Лайлива лексика}

Величезна кількість лінгвістичних одиниць вважаються прокляттями та лайкою; складні вирази, які знаходять у змісті релігійних, правових та інших офіційних текстах. Водночас $€$ велика кількість одиниць, які використовуються у повсякденному житті і виражають ненависть, здивування, розгубленість. Найчастіше використовуються в англійській мові ті, які мають різний рівень експресивності. Наприклад, м'які “heck”, “dash" та сильне, грубе "fuck".

6) Слова на позначення приватності

Однією з причин виникнення табу на питання про особисте $\epsilon$ цінування англійцями приватного життя. В англійців $є$ приказка “A man's home is his castle”, яка говорить про те, що дім є священним для англійців, ніхто не може втручатися і приходити без дозволу. Так само і особисте життя для них $€$ важливим. Ставити питання, які стосуються віку, ваги, прибутку, сімейного стану, політичних поглядів, релігії тощо, будуть розглядатися як втручання в особисте життя. "It's none of your business" таку відповідь часто можна почути, якщо поставити хоча б одне 3 питань: "How old are you?", "What's your income?", "What's your religion?", "Are you married?", "Where are you going?", "How much did you pay for that?" (Chunming, 2013).

Не менш важливим моментом у вивченні евфемістичних одиниць $є$ вивчення їх функціонування. У своїй праці В. І. Великорода виділяє такі основні функції евфемізмів, як: вуалітивна, кооперуюча, превентивна, риторична, елевативна, конспіративна та дистортивна (Великорода, 2008).

Вуалітивна функиія показує прагнення мовця приховати певні аспекти, про які він не хоче відверто говорити. Ця функція притаманна всім евфемізмам, особливо чітко простежується у промовах політиків та громадських діячів. У таких випадках, щоб приховати реалії, які можуть викликати негативну реакцію суспільства, використовують одиниці "game" (war), "rectification of frontiers", "transfer of population" (deportation), "to stretch the truth, to embroider the truth" (to lie) (ICALTEFL).

Кооперуюча функиія спрямована на прагнення комунікантів до співпраці та вирішення певних завдань. Притаманна більшості евфемізмів, але чітко проявляється у евфемізмах, які допомагають уникненню дискримінації. Наприклад: "vertically challenged" (short), "physically handicapped" (crippled), "developmentally disabled" (retarded), "hearing-impaired" (deaf) (Великорода, 2008).

Преветивна функція спрямована на використання евфемізмів, які ще збереглися у свідомості людей, але є альтернативою давнім табу (позначення фізіології людини, смерть, релігія тощо): 
"Cape of Good Hope", "Temple of Venus" (female genitals), "Father of Lies", "old boy", "Prince of evil" (devil), "Creator", "Almighty", "Savior" (God), "to sleep" (to be dead), "to answer the final summons", "to pass away" (to die).

Риторична функиіл - мовець намагається певним чином впливати на ціннісні упередження адресата, намагання змінити його ставлення та спонукати до певних дій: "to re-engineer" (to fire), "de-luxe" (expensive), "economy" (cheap), "message" (commercial).

Елевативна функція - аспекти реального світу представляються адресантом як перебільшення стандартів низького та середнього рівня. Сюди відносять назви непрестижних професій, товарів, організації, на які не звернули б увагу без перебільшення їх якостей: "large” (medium-sized), "averagelooking" (ugly), "embalming surgeon" (undertaker), "access controller" (doorman), "sanitation engineer" (dustman), "podiatrist", "chiropodist" (corn-cutter) (Великорода, 2008).

Конспіративна функція - навмисна евфемізація неприйнятного членами певних суспільств, професійних, вікових груп задля ускладнення розуміння інформації іншими групами: "magpie", (machine-gun), "company", "customer" (CIA, FBI), "to hemorrhage" (to bleed), " $D \& C$ " (abortion). Ця функція дає можливість ідентифікувати членів однієї і тієї ж групи між собою, тоді як інші не розуміють їх, не можуть адекватно інтерпретувати інформацію, яка $є$ зашифрованою. Тісно пов'язана із функціонуванням арго (слова та вирази, що обмежено вживаються в мові окремих соціальних груп).

Дистортивна функиія спрямована на відображення вживання евфемізмів, які спотворюють інформацію, яка відображається у свідомості адресата, може функціонувати як результат вуалітивної чи конспіративної функції і притаманна евфемізмам, що відносять до медицини, політики, реклами. $€$ близькою до вуалітивної, але остання має масштабніший характер. Дистортивна функція негативно впливає на комунікацію і знижує іiі ефективність: "democracy" (dictatorship), "rescue mission", "brotherly help" (invasion) (Великорода, 2008).

Висновки. У кожній спільноті присутні речі, які соромно або неприємно говорити. Саме тому вживання прямих відповідників деяких слів не $\epsilon$ толерантним, для цього використовують евфемізми, які виконують пом'якшувальну роль, вони $\epsilon$ толерантним вираженням заборонених висловів. Варто пам'ятати, що те, що є дозволеним в одному суспільстві, може бути забороненим в іншому, отже, перш ніж говорити, варто подумати.

Нині у час, коли існує величезний потік інформації, неймовірно важко цю інформацію диференціювати. Подані функції виражають різні наміри для використання будь-якої інформації, адже, як відомо, часто інформація використовується 3 метою впливу на адресанта та зміни його думок, упереджень, а іноді 3 метою нанесення певної шкоди. Саме тому вивчення засобів ефемізації $€$ не лише цікавим, а й корисним.

\section{СПИСОК ВИКОРИСТАНИХ ДЖЕРЕЛ}

1. Великорода В. Б. Семантичні та функціонально-прагматичні характеристики евфемізмів в англійській мові : автореф. дис. на здобуття наук. ступеня кан-та філол. наук : 10.02.04. Львів, 2008. 20 с.

2. Денисенко Я. Ю. Евфемізми в англійській мові. Соціально-гуманітарні аспекти розвитку сучасного суспільства : зб. матеріалів Всеукр. наук. конф., 19-20 квіт. 2012 р. Суми, 2012. С. 26-28.

3. Chunming Gao. A Sociolinguistic Study of English Taboo Language. Theory and Practice in Language Studies. 2013. Vol. 3, No. 12, P. 2310-2314.

4. Born Still: Euphemism and the Double-Taboo of Women's Bodies and Death : вебсайm. URL: http://homes.chass.utoronto.ca/ cpercy/courses/6362-CrawfordAllison.htm (дата звернення: 10.01.2021).

5. Taboo Words and TEFL : вебсайm. URL: http://www.icaltefl.com/taboo-words-and-tefl (дата звернення: 20.02.2021).

\section{REFERENCES}

1. Velykoroda, V. B. Semantychni ta funktsionalno-pragmatychni harakterystyky evfemizmiv v anhliys'kiy movi [Semantic and functional-pragmatic characteristics of euphemisms in English language] : avtoref. dis. na zdobuttya nauk. stupenia kand. filol. nauk : 10.02.04. Lviv, 2008, 20 p. [in Ukrainian].

2. Denysenko, Ya. V. Evfemizmi v anhliys'kiy movi [Euphemisms in English language]. Sotsial'no-humanitarni aspekty rozvytku suchasnoho suspil'stva: zb. materialiv Vseukr. nauk. konf., 19-20 kvit. 2012 r. Sumy, 2012. P. 26-28 [in Ukrainian].

3. Chunming Gao. A Sociolinguistic Study of English Taboo Language. Theory and Practice in Language Studies. 2013. Vol. 3, No. 12, P. 2310-2314 [in English].

4. Born Still: Euphemism and the Double-Taboo of Women's Bodies and Death: web-site. Retrieved from: http://homes. chass.utoronto.ca/ cpercy/courses/6362-CrawfordAllison.htm [in English].

5. Taboo Words and TEFL: web-site. Retrieved from: http://www.icaltefl.com/taboo-words-and-tefl [in English]. 